
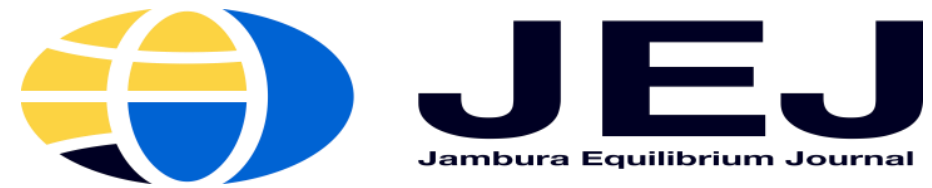

Volume 3. Issue 2. 2021

P-ISSN 2655-9110

E-ISSN 2656-0445

http://ejurnal.ung.ac.id/index.php/equij

\title{
The Impact of Covid-19 on the Effect Multiplier on the Household Consumption Function in Jakarta
}

\author{
Fahrul Rizal, Michael Christianto Leonardo ${ }^{2}$ \\ Faculty of Social Science and Humanities, Universitas Bunda Mulia, Jakarta, Indonesia ${ }^{1,2}$
}

\begin{abstract}
The purpose of this study is to examine the effect of a decrease in aggregate income, due to activity restrictions during the Covid-19 pandemic, on household consumption expenditure in Jakarta. The research model is based on the Absolute and Permanent income hypothesis, to see the long-term and short-term effects of changes in income on consumption expenditure. The research method is quantitative by using annual data on consumption expenditure and income at current prices for the period 2003 to 2020. The analysis model uses $O L S$ and ECM regression. The results showed that income has a significant effect on the equation of the short-run and long-run consumption function. The short-term income crisis has an impact on the increase in the multiplier coefficient. In the short term there will also be an adjustment in consumption expenditures, according to what is postulated in the permanent income hypothesis. This indicates that in the short term expansionary fiscal policy is effective in increasing aggregate household consumption expenditure. Further research suggests adding the inflation variable as a proxy for economic conditions.
\end{abstract}

\section{Keywords: Absolute Income Hypothesis; Permanent Income Hypothesis; Household} Consumption Expenditure; National Income; Multiplier

\section{INTRODUCTION}

Household is one of the most dominant economic actors in an economy in all countries. This can be proven by the large contribution of household expenditures to gross domestic product (GDP) (İsmihan, 2019). The contribution of household consumption to the total gross domestic product will have implications for the magnitude of the influence of household consumption behavior on the economy (Al Gahtani et al., 2020). With the dominance of household consumption in the component of aggregate demand, household consumption is a variable that has great potential to drive inflation in the economy (Martin et al., 2020). So that the contribution of household consumption to gross domestic product is a variable that must be monitored in an economy.

The covid-19 virus outbreak, which continues to spread, has had a significant impact on macroeconomic variables such as National Income, unemployment and inflation. For the 2020 full year, Indonesia's GDP contracted by $2.07 \%$, the steepest decline since the 1998 Asian financial crisis, reversing from a 5.02\% growth in 2019. The worst contraction was in the 3rd quarter, $-3.49 \%$. The period was the third straight quarter of contraction 
amid the coronavirus pandemic and there was a $2.19 \%$ shrinking growth in the fourth quarter. Another impact is that the Central Statistics Agency (BPS) recorded calendar year inflation during 2020 of 1.68 percent, the lowest in history.

As a National Capital, Jakarta's economy, which is dominated by the service and trade sectors, has been severely affected by the outbreak.. In the third quarter of 2020, economic growth in Jakarta was still contracted by minus 3.82 percent (y-on-y), which in the previous period, in the second quarter, reached minus 8.23 percent. Economic pressures during these two quarters have implications for household purchasing power. Domestic demand, such as household consumption and investment, is still low and has not shown any improvement, made it difficult to improve the economy. However, as a result of limiting activities, the growth rate of Jakarta's consumption expenditure in 2020 has fallen sharply (-2.08 percent).

To balance these pressures, government consumption, especially those related to spending to deal with Covid-19, has increased very significantly. However, these efforts have not been able to restore the strength of domestic expenditures as the motor of growth. Referring to the macroeconomic theory theorized by J.M Keynes, effective fiscal policies, reducing taxes and increase government expenditure are the key instruments in supporting economic recovery, especially in Low Income Countries (LICs) and Lower Middle Income Countries (LMICs) (Arvin et al., 2021). In order to prevent a further decline in the economy, the central and provincial governments issued several fiscal policies such as tax exemptions, direct subsidies and increased spending on basic necessities and food provided to income-affected people. The effectiveness of fiscal policy in lifting national income is influenced by the level of the multiplier obtained from the marginal propensity to consume (MPC) of the aggregate household consumption function.

Absolute Income Hypothesis, Keynes' consumption expenditure theory, postulate that disposable income determines household consumption expenditure (Saraswati \& Khusaini, 2018), in his theory, he also postulates that the interest rate does not significantly influence consumption expenditure (Mankiw, 2016). In sum, in dealing with the economic crisis caused by the pandemic, fiscal policy is the most effective way to restore the economy than monetary policy (Riza \& Wiriyanata, 2021).

Milton Friedman has a different view and puts forward the theory of the Permanent Income hypothesis (PIH). He postulated consumption and income are nonstationary variables decomposed series of consumption and income into dual permanent and transitory - component in order to understand their permanent and temporary movement (İsmihan, 2019). Therefore, consumption expenditure is not only affected by permanent income but also transitory income (Flavin, 1993).

The permanent income hypothesis states that individuals will spend money at a level that is consistent with their expected long-term average income. Milton Friedman developed the permanent income hypothesis, basic cognitive process that household spend their income as a results of calculable future income as against consumption that's supported current aftertax financial gain.. Under this theory, any fiscal policies related to increase the absolute income will no significantly affect on increasing consumer spending, unless permanent income. An individual's liquidity could be a consider their management of financial gain and payment.

The hypothesis implies that changes in consumption behavior don't seem to be sure as a result of they're supported 
individual expectations. This has broad implications regarding policy. Under this theory, albeit economic policies have no mean in increasing consumption spending within the economy, the policies might not set out a number result with regard to inflated consumer defrayment. Rather, the speculation predicts that there'll not be associate dealing in consumption defrayment till household reform expectations regarding their future incomes.

Milton postulated that people will spend their money based on an estimate of their future income. This postulate differs from Keynes's theory economics proposed; people will consume based on their in the moment after-tax income. Milton's basis was that individuals prefer to smooth their consumption rather than let it bounce around as a result of short-term fluctuations in income (Kim, 2017).

The economic impact of COVID-19 starts as a negative supply shock (Hausmann, 2020) has lead to a demand shock. Using the moment of income shock due to the Covid-19 outbreak, this study aims to examine the impact of Covid-19 outbreak on multiplier household consumption function in Jakarta. Was there a change in the multiplier effect of the short-term consumption function between before and after the Covid-19 outbreak?

\section{Permanent Income Hypothesis}

A solid form of Permanent Income Hypothesis requires that while perpetual utilization is controlled by lasting pay, brief utilization and momentary pay are inconsequential (Friedman, 1957). Notwithstanding, it is additionally conceivable that lasting and transient segments of utilization may have separate co-developments and thus double change, utilization not just reacts to the progressions in perpetual pay (as in a solid variant of the theory), yet additionally to the progressions in short lived pay (Ismihan, 2019).

Contending that both Permanent Income Hypothesis and traditional consumption function play some roles in explaining the aggregate consumption behavior, Ismihan (2019) considering a double design of the co-moving factors utilized Co-HP moving and double change approach as an option in contrast to the prevailing methodology for displaying nonstationary factors, which are close to home utilization and discretionary cashflow.

In sum, this examination proposes a straightforward methodology for assessment and testing of dual adjustment with an application to the consumption function using the Indonesian data over the period. Consider a simplified version of Permanent Income Hypothesis (PIH) as follows

$$
\begin{gathered}
C_{t}=k Y_{t}^{P}+V_{c t} \\
Y_{t}=Y_{t}^{P}+V_{y t}
\end{gathered}
$$

$C$ represent as consumption and $Y$ is disposable income, $Y^{p}$ is permanent disposable income and $V_{c t}$ and $V_{y t}$ are transitory consumption and income, respectively. Subsequently, in this simple set-up, current consumption comprises of permanent consumption and transitory consumption $C=C^{P}+V_{C}$ and permanent consumption is assumed to be proportional to the permanent disposable income $C^{P}=$ $k Y^{P}$.Thus, $\mathrm{C}$ and $\mathrm{Y}$ share a common (stochastic) trend. Since the PIH implies that consumption and disposable in-come will share a common stochastic trend, these variables will be cointegrated (Stock, 1988:401).

Verter (2014) examines household consumption in the Czech Republic for the period 1993-2012, using additional variables, inflation and savings as independent variables. The model was analyzed using regression and Granger 
causality test. The results show that income has a positive effect on consumption while inflation and savings have a negative effect on consumption. In addition, this study confirms the causal relationship of household saving-consumption and household consumption-inflation. The same findings from Varmalova (2015) examined the effect of macroeconomic and demographic factors on household consumption expenditure in 34 OECD countries in 2012, using multiple regression. The results of this study indicate that disposable income, government spending, inflation, interest rates, population and education level are proven to have an effect on household consumption expenditure.

\section{Absolute Income Hypothesis}

Keynes treated consumption on an exceptionally "presence of mind" level. As indicated by Keynes an economic agent by common nature tends generally speaking and overall, to expand his utilization as his income rises, however not by as much as the increment in his pay. In his work on the connection among income and consumption, he came out with the finding that disposable income (income minus tax) is the sole determinant of utilization (Tsenkwo, 2011). In view of Keynesian consumption function, the Absolute Income Hypothesis (AIH, from this point forward), total consumption is a stable, yet not really direct, capacity of disposable income.

$$
\begin{gathered}
C=\alpha+\beta Y_{t} \\
\mathrm{C}_{\mathrm{t}} \quad \text { denotes total household }
\end{gathered}
$$
consumption expenditure and $\mathrm{Y}_{\mathrm{t}}$ denotes disposable income at time t. $\beta$, the marginal propensity to consume (MPC) is expected to be constant and positive but less than 1 . In sum, higher income will lead to higher consumption. The autonomous consumption $(\alpha)$ is assumed to be small and positive. The important feature of the absolute income hypothesis are: (1) the consumption expenditure is changed as the income changed but nit proportionally. This non-proportionally changes due to in the short run average propensity to consume (APC) is greater than the MPC (APC $>$ MPC). Where $\mathrm{APC}=\mathrm{C} / \mathrm{Y}$ and $\mathrm{MPC}=\Delta \mathrm{C} / \Delta \mathrm{Y}$. Autonomous consumption do not change with income in the short time frame, unless over the long period. Consumption will rise when wealth and income increase. The marginal propensity to consume in the long run income will closer to the average propensity to consume.

The MPC determines the magnitude of the multiplier effect. The multiplier effect shows the amount of additional income achieved as a result of additional government spending, investment or net exports.The multiplier effect works only when fiscal spending creates new employment and the deflationary gap shrinks (Murota \& Ono, 2012)

\section{Household Consumption Expenditures}

Household Expenditures are all expenses of family and individual households as well as non-company private institutions to purchase goods and services that can be directly used to meet needs. Household expenditure is an indicator of individual and social welfare. The level of household expenditure shows the level of development of the overall economic system (Illahi, Adry, \& Triani, 2019).

Many factors influence the amount of household consumption expenditure. These factors can be classified into economic factors, demographic factors and non-economic factors. Economic factors that affect the level of household consumption are household income, household wealth, the number of durable consumer goods in society, interest rates, 
forecasts about the future, and government policies to reduce inequality in income distribution. Demographic factors that affect the level of consumption are population size and population composition. Meanwhile, the noneconomic factors that most influence the level of consumption are socio-cultural factors such as eating habits, changes in ethics and values to imitate other community groups (Rahardja and Manurung, 2008).

Household consumption is the largest contributor, around half, of a country's Gross Domestic Product. Thus, consumption expenditure has an important impact in influencing the ups and downs of the economy from year to year. When in the long run, consumption and saving will affect economic growth (Sukirno, 2000).

During the economic crisis in 19971998, restoring household consumption expenditure was the main strategy undertaken by the government to recover the economy from the crisis. The increase in consumption expenditure was driven up to 70 percent of GDP in 1999. Consumption really helped in the increase and its peak occurred in 1999 where its share in GDP reached 70 percent. (Bank Indonesia, 2007).

Varlamova, dan Larionova,. (2015) examines the effect of monetary shocks represented by the interest rate variable on consumption in Spain. The result is that changes in the interest rate have an impact on household consumption with a larger portion of the residential effect than the wealth effect. Previously, Tapsin (2014) discussed the effect of income factors on consumption. By using panel data for the period 2009-2012, the result is that the MPC in the consumption model by removing the income variable is greater than the MPC by removing financial assets, which means that the financial assets owned have a greater influence on consumption than income.

\section{METHODOLOGY}

Error correction modelling (ECM) relies on the existence of long run stable relationship between non stationary time series. The relationship is tested with the cointegration framework, most commonly using the multivariate Johansen methodology. The use of original, not seasonally adjusted data, adds a seasonal component and, if the seasonality is found to be non-stationary, the methodology is adapted to incorporate seasonal cointegration testing (Williams, 1999).

ECM make use of the specific time series properties to correctly specify the model. In an ECM, the dependent variable and some of the independent variables are expressed in first difference term to capture the short run dynamics of the model, critically, one of the explanatory variables is the error correction term. Error correction term is derived from the long run (cointegrating) relationship between the variables and captures the long rum dynamics model. Only the error correction from the model, therefore incorporates both the short run and long-run dynamics of the relationships between the variables.

ECM equation can be expressed as follow:

$$
\Delta y_{t}=\sum_{i=1}^{k} \sum_{j=0}^{p} \alpha_{i j} \Delta x_{i t-j}+\delta\left(y_{t-1}-\sum_{i=1}^{k} \beta i x_{i t-1}\right)+\varepsilon_{1}
$$

The analysis uses ECM if the variables are cointegrated and stationary at the same level. So, to use the ECM model, it is necessary to test for stationarity and data cointegration, before proceeding to the next stage of analysis. 
We used the Keynesian AIH to be tested empirically using the ordinary least squares as:

Cons $=\alpha+\beta 1 Y$

The Keynesian model is used to estimate the MPC in the long run, and as a basis for finding the multiplier number. In the above equation $\beta 1$ refer to long term MPC (İsmihan, 2019).

Friedman's permanent income hypothesis is use to determine the effect in the short run, the consumption equation model is transformed into an ECM regression model as follows:

DCons $=\alpha+\gamma 1 Y+\eta C^{t}$

The permanent income hypothesis equation model is used to investigate whether there is a transitory consumption of income in the short-term relationship, and to investigate whether there is a difference between the MPC score of the long-run and the shortrun equation. In short term equation $\gamma$ refer to short-term MPC and $\eta$ refer to transitory consumption $\left(\mathrm{C}^{\mathrm{t}}\right)$.

We use gross regional income (PDRB Jakarta) as a proxy for income and household final consumption expenditure as a proxy for consumption. Data for the series are in IDR million and are collected from Bank Indonesia and Badan Pusat Statistik Jakarta. The data spans the time period from 2003-2020, total are 18 observation. We start by defining $\mathrm{Y}$ as the gross national income and Cons as household total consumption expenditure.

\section{RESULTS AND DISCUSSION}

\section{Results}

Figure 1 shows a graph of aggregate consumption and aggregate household income in Jakarta for the period 2003Q1 to 2020 Q4.

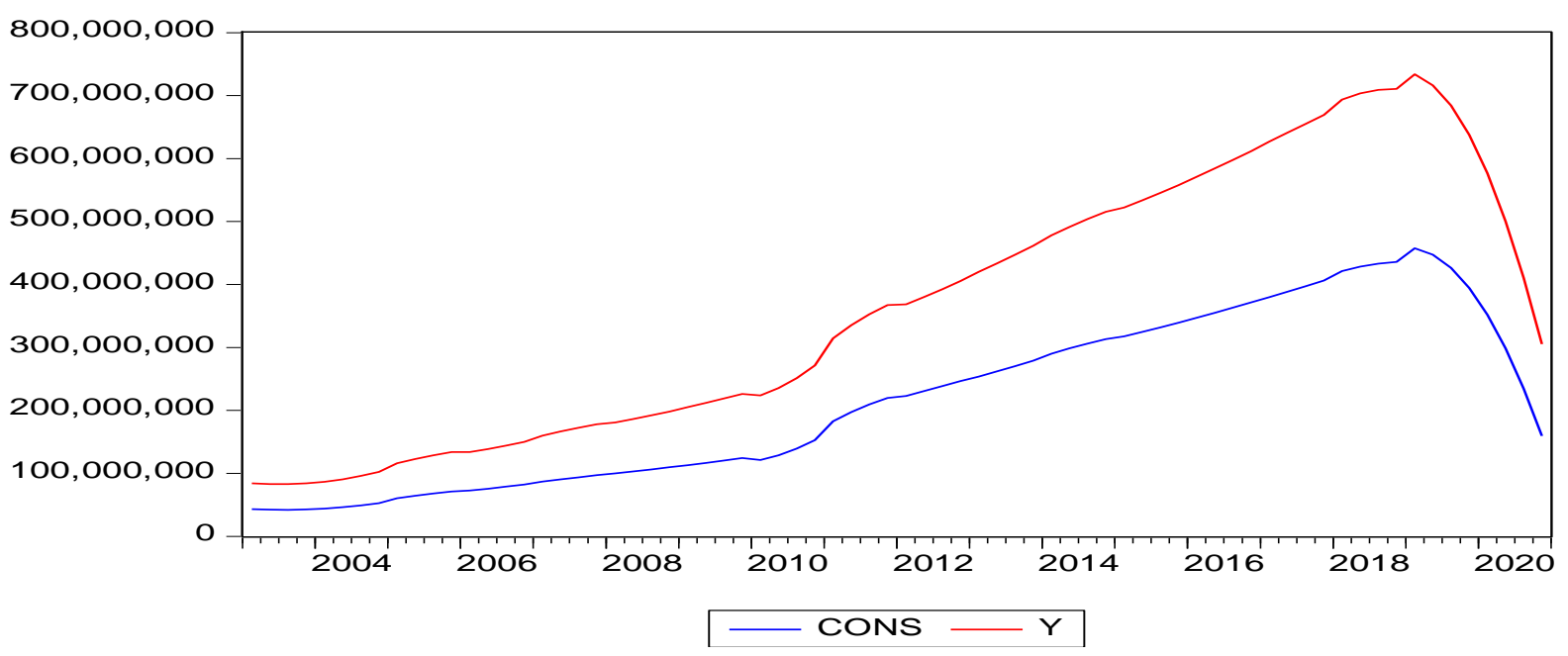

Processed with eviews-9

Figure 1. Consumption Expenditure and Income

\section{Source: Badan Pusat Statistik-Jakarta}

Consumption and income have an increasing trend from 2003 to 2019. The data recorded the highest consumption expenditure in the first quarter of 2019 with the consumption value $\mathrm{Rp} 457.760 .940,2$ million. However, in 2020 The economy has contracted due to the Covid-19 pandemic outbreak. Consumption expenditure in the 4th quarter of 2020, experienced a sharp decline to IDR $159,451,848.7$ million. From this curve, it can be ascertained that there is a shock in 
aggregate demand due to a decrease in aggregate income.

\section{Unit Root Test}

The unit root test was carried out to ensure the level of data stationarity. Unit root test is performed to avoid spurious regression. Stationary test was performed using the ADF-Fisher Chi Square. Figure 2 shows the results of the stationary test data.

\section{Table 1. Unit Root Test}

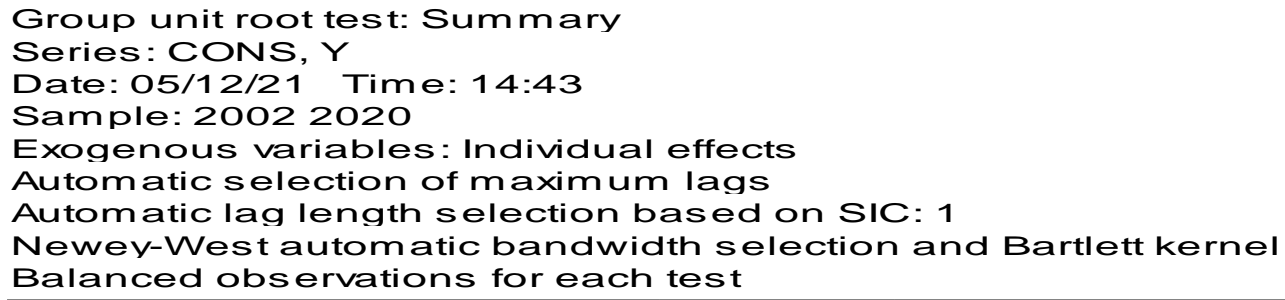

\begin{tabular}{|c|c|c|c|c|}
\hline Method & Statistic & Prob.** & $\begin{array}{c}\text { Cross- } \\
\text { sections }\end{array}$ & Obs \\
\hline \multicolumn{5}{|c|}{ Null: Unit root (assumes common unit root process) } \\
\hline Levin, Lin \& Chu $\mathrm{t}^{\star}$ & -3.60648 & 0.0002 & 2 & 34 \\
\hline \multicolumn{5}{|c|}{ Null: Unit root (assumes individual unit root process) } \\
\hline Im, Pesaran and Shin W-stat & -1.94989 & 0.0256 & 2 & 34 \\
\hline ADF - Fisher Chi-square & 10.6573 & 0.0307 & 2 & 34 \\
\hline PP - Fisher Chi-square & 1.72901 & 0.7854 & 2 & 36 \\
\hline
\end{tabular}

** Probabilities for Fisher tests are computed using an asymptotic Chi -square distribution. All other tests assume asymptotic normality.

\section{Processed with eviews-9}

The test results show that the consumption and income data are stationary at the level. Thus, the regression with the OLS model can be applied.

\section{Cointegration Test}

Cointegration test is to test for the existence of long-run equilibrium relationships in the levels among variables.
Because the variables of interest in this study are two, Consumption and income we adopted Eagle-Granger (EG )to test the existence of cointegration. The EG test involves testing for stationarity of the residuals (Enders, 2010). If the residual series is stationary, the variables consumption and income are cointegrated. The cointegration test using the PhillipPerron showed the residual value has been stationary at the level. 
Table 2. Cointegration

Null Hypothesis: ECT has a unit root

Exogenous: Constant

Bandwidth: 1 (Newey-West automatic) using Bartlett kernel

\begin{tabular}{lccc}
\hline \hline & Adj. t-Stat & Prob.* $^{*}$ \\
\hline \hline Phillips-Perron test statistic & -3.503096 & 0.0204 \\
\hline Test critical values: & $1 \%$ level & -3.857386 & \\
& $5 \%$ level & -3.040391 & \\
& $10 \%$ level & -2.660551 & \\
\hline \hline
\end{tabular}

*MacKinnon (1996) one-sided p-values.

Warning: Probabilities and critical values calculated for 20 observations and may not be accurate for a sample size of 18

Processed with eviews-9

Thus it can be concluded that $\mathrm{Y}$ and Cons are cointegrated and each other make adjustments in the long run.

\section{Long-Term Equation Model}

The data is processed using E-

Views 9. OLS model regression is used to estimate the long-run consumption function equation. The estimation result of parameter B1 which is the MPC of the consumption function is $\beta 1=0.63$, significant at alpha $<0.01$. The autonomous consumption value $(\alpha)$ is 53.052 .097 , significant at alpha $<0.01$. The consumption equation is written as follows:

$$
\begin{array}{lcl}
\text { SE } & 6778966 & 0.0041 \\
\text { t-stat } & (-7.82) & (152.15)
\end{array} \text { Cons }=-53052097+0.63 Y
$$

$\mathrm{R}^{2}=0,999$

F-Stat $=23160.32$

$\mathrm{DW}=1.692$

Jarque-Bera normality test of 0.483 (Prob. 0.786) indicates that the error is normally distributed.

Heteroscedasticity test with Glejser shows probability $\mathrm{F}$ statistic $>0.05$. Thus, it can be ascertained that heteroscedasticity does not occur heteroscedasticity in the regression model.
Breusch-Godfrey serial correlation test, the probability value of F-statistics is significant $>0.05$, indicating that there is no autocorrelation in the model. The probability value of the Ramsey Reset test $t$ statistic $>0.05$ indicates that $\mathrm{Y}$ has a linear effect on Consumption 
Table 3. Long-run Consumption Function Classical Assumptions Test

\begin{tabular}{lll}
\hline Classical Assumptions & Test & Prob \\
\hline Normality Distribution & Jarque-bera & 0,786 \\
Heteroscedasticity & Glejser & 0.65 \\
Linearity & Ramsey-Reset & 0.177 \\
Autocorrelation & Breusch-Godfrey & 0,99 \\
\hline
\end{tabular}

Processed with eviews-9

Because the Keynesian function model fulfills all the requirements of the classical assumption test, the estimation on parameter B1 meets the requirements for interpretation.

The regression equation model shows that the autonomous consumption has a negative value. This is because the data used is still in the form of gross income, not in the form of net income, due to data limitations. The MPC value in the long-run equation is 0.63 , which means that consumption expenditure increases by $\mathrm{Rp}$. 630,000 , if the income increases by $\mathrm{Rp}$. $1,000,000$.

The multiplier function of consumption to income is obtained by using the 1/1-MPC formula. The multiplier effect is 2.7 , which means that an increase in other components of national income by Rp. 1 will increase national income by Rp. 2.7. If it is assumed that the government expands fiscal expenditure by Rp. 1 billion, it will increase national income by Rp. 2.7 billion.

\section{Short Run Equation Model}

The short-run equations are obtained using differential level 1 data for $\mathrm{Y}$ and Cons, respectively, and adding the ECT variable as a correction. The ECM regression model is eligible if the ECM coefficient is negative and significant, Short-term regression indicates ECT has a significant effect at alpha $<0.1$ in adjusting for short-term consumption expenditure. The equation for the short-run consumption regression function can be written as follows:

$$
\begin{aligned}
& \text { dCons }=-4368590+0.66(d Y)-0,64 E C T \\
& \text { Se } 3698190 \quad 0.0145 \quad 0.0337 \\
& \text { t-stat } \quad(-1.18) \quad(45,76) \quad(-1,90) \\
& \text { The classical assumption test applies to the of the regression parameters. A summary of } \\
& \text { the test results is presented in table } 2 \text {. }
\end{aligned}
$$
short-run model to determine the feasibility

Table 4. Short-run Consumption Function Classical Assumptions Test

\begin{tabular}{lll}
\hline Classical Assumptions & Test & Prob \\
\hline Normality Distribution & Jarque-bera & 0.007 \\
Heteroscedasticity & Glejser & 0.1866 \\
Linearity & Ramsey-Reset & 0.1352 \\
Autocorrelation & Breusch-Godfrey & 0,087 \\
\hline
\end{tabular}

Processed with eviews-9

The test results indicate that all classical assumption tests pass, unless for the normality test (probability of Jarquebera < 0.05). However, the requirements for the ECM model, i.e. the ECT are negative and significant, meet the requirements of the ECM regression model, thus, the parameters still qualify for interpretation.

The ECM regression explains the short-run relationship of changes in income to changes in consumption expenditure. The short-term MPC 0.66 explains that in 
the short term if there is an additional income of Rp. $1,000,000$ then the consumption expenditure will increase by Rp. 660,000. However, in the short term, there is an adjustment in the value of consumption expenditure of 0.64 from the ECT value. So that in the short run the MPC of the consumption function is less than 0.66 .

The multiplier of the short-run consumption equation is $1 / 1-0.66=2.94$, higher than the multiplier of the short-run consumption function. Income shocks due to restrictions on the scale of activities to reduce covid-19 transmission have an impact on the increase in the value of the MPC. This condition is in accordance with the prediction from Keyness, that the lower the household income, the greater the MPC and APC

\section{Estimating the multiplier effect.}

By obtaining the long-run and shortrun consumption equations, now it is possible to estimate the multiplier effect. the cointegration between $\mathrm{C}$ and $\mathrm{Y}$ allows for the interaction between $\mathrm{C}$ and $\mathrm{Y}$. An increase in $\mathrm{Y}$ will increase $\mathrm{C}$, vice versa. The results showed that there was an increase in the multiplier effect in the short term from 2.7 to 2.9. A higher multiplier value increases the effectiveness of the expansionary fiscal policy carried out by

\section{CONCLUSION}

This article provided estimations of the effects of a decrease in income on household consumption expenditure in Jakarta using data from the 2013 to 2020 . The Covid-19 outbreak has an impact on decreasing Jakarta's household income in aggregate, and decreasing household consumption expenditure.cThe pattern of household consumption expenditure in the long run follows the hypothesis of the the government during times of crisis due to pandemics. The results of this study are in line with Murota \& Ono, (2012). In the steady state with demand shortage and deflation consumption is a function of aggregate demand and aggregate demand is determined in a way similar to the Keynesian cross. Multiplier effect will works when expansive fiscal expenditure creates new employment opportunity and the deflationary gap shrinks. This study is in line with research conducted by İsmihan, (2019), which confirms dual adjustments in income to consumption expenditure in the short term.

The next finding is that the economic crisis due to the pandemic has increased the allocation of consumption expenditures to household income in Jakarta. Households allocate a large part of their income that has been reduced due to the crisis for household consumption expenditures, especially on the purchase of basic commodities. The results of this study are in line with the research of Saraswati and Khusnani (2018) which states that the economic crisis has been shown to have a positive and significant effect on the increase in the value of household consumption. The ECT coefficient value of -0.64 as an adjustment for short-term consumption indicates a portion of the income earned is saved for precautionary needs.

absolute income hypothesis, but in terms of the comparison of the value of APC and MPC there is a difference, where the finding is that the APC is lower than the MPC.

In the short-run consumption function, the pattern of household consumption expenditure in Jakarta is relevant to the theory of the permanent income hypothesis, indicated by the MPC value equal to the APC, and there is an adjustment in consumption expenditure, 
indicated by the significance of the ECT coefficient.cCovid-19 has had the impact of changing the multiplier function of income in Jakarta. The multiplier effect after the outbreak has increased compared to that before the outbreak. A higher multiplier indicates that economic recovery measures through expansionary fiscal policy will be more effective.

\section{REFERENCES}

Al Gahtani, G., Bollino, C. A., Bigerna, S., \& Pierru, A. (2020). Estimating the household consumption function in Saudi Arabia: an error correction approach. Applied Economics, 52(11).

https://doi.org/10.1080/00036846.2 019.1659933

Arvin, M. B., Pradhan, R. P., \& Nair, M. S. (2021). Are there links between institutional quality, government expenditure, tax revenue and economic growth? Evidence from low-income and lower middleincome countries. Economic Analysis and Policy, 70, 468-489. https://doi.org/10.1016/j.eap.2021. 03.011

Enders, W. (2010). Applied econometric time series. Hoboken, NJ: Wiley.

Flavin, Ma, (1993). The excess smoothness of consumption: identification and interpretation. Rev. Econ. Stud. 60, $651 \mathrm{e} 666$.

Bank Indonesia. (2007). Suku Bunga Konsumsi, Analisis Ekonomi. Jurnal Ekonomi dan Bisnis Research

Illahi, N., Adry, M. R., \& Triani, M. (2019). Analisis Determinan Pengeluaran konsumsi Rumah tangga di Indonesia. Jurnal Ecogen, 1 (3), 549. doi:10.24036/jmpe.v1i3.5025

İsmihan, M. (2019). The dual adjustment approach with an application to the consumption function. Central
Bank Review, 19(1), 1-8. https://doi.org/10.1016/j.cbrev.201 9.02 .001

Kim, H. Y. (2017). The permanent income hypothesis, transitional dynamics, and excess sensitivity of consumption. Structural Change and Economic Dynamics, 40, 1025. doi:10.1016/j.strueco.2016.10.001. Mankiw, Gregory.

(2016). Macroeconomics. Nine edition. Worth Publisher 2016.

Martin, A., Markhvida, M., Hallegatte, S., \& Walsh, B. (2020). Socioeconomic impacts of COVID-19 on household consumption and poverty. In arXiv. https://doi.org/10.1007/s41885020-00070-3

Murota, R., \& Ono, Y. (2012). A Reinterpretation of the Keynesian Consumption Function and Multiplier Effect. SSRN Electronic Journal. https://doi.org/10.2139/ssrn.162203 $\underline{6}$

Rahardja dan Manurung (2005) Teori Ekonomi Makro . Edisi Ketiga. Fakultas Ekonomi Universitas Indonesia: Jakarta

Riza, F., \& Wiriyanata, W. (2021). Analysis of the viability of fiscal and monetary policies on the recovery of household Consumption expenditures because of the Covid-19 pandemic. Jambura Equilibrium Journal, 3(1). doi:10.37479/jej.v3i1.10166.

Saraswati, B. D., \& Khusaini, M. (2018). Pengaruh Krisis Ekonomi Terhadap Fungsi Konsumsi Rumah Tangga di Indonesia Penerapan: Absolute income hypothesis. Jurnal Ekonomi Kuantitatif Terapan, 137. doi:10.24843/jekt.2018.v11.i01.p1 1 
Stock, J. (1988). A Reexamination of Friedman's Consumption Puzzle. Journal of Business \& Economic Statistics, $\quad 6(4), \quad 401-407$. doi:10.2307/1391450

Sukirno, Sadono. (2000). Makroekonomi Modern. Jakarta: PT Raja Drafindo Persada.

Tapsin, Gulcin. (2014). An analysis of household consumption expenditure EA-18. Journal European Scientific.Countries". Hlm. 727-733.

Tsenkwo, J.B. (2011). Testing Nigeria's Marginal Propensity to Consume (MPC) Within the Period 19802004. Journal of Innovative Research in Management and Humanities, 2(1).

Varlamova, J dan Larionova, N. (2015). "Macroeconomic and Demographic of Household Expenditure in OECD Composition Approach to Fiscal Policy Instruction for Principles Students". Journal of Economics Education, 153-173.

Varlamova, J.and Larionova (2015). Macroeconomics and Demographic determinants of Household Expenditure in OECD Countries. Procedia Economics and Finance 24, 727-733

Verter, Nahanga. (2014). A Time Series Analysis of Macroeconomic Determinant of Household Spending in The Era of CrossCultural Dynamic Czech Republic as a Case Study. Procedia Economics and Finance 12, 733742.

Williams, C. (1999). Estimating a consumption function for Queensland**The views and information contained in this paper are not necessarily the opinions or views of Queensland Treasury or the Queensland Government.
Economic Analysis and Policy, 29, 71-92. doi:10.1016/s03135926(99)50040-4 